\title{
Effect of Notice of Tax Warning, Notice of Tax Collection, and Tax Education Programs on Tax Compliance in West Sumatera and Jambi
}

\author{
Indra Budiman ${ }^{1^{*}}$, Inayati ${ }^{2}$ \\ ${ }^{1 * 2}$ Faculty of Pubic Policy Administration, University of Indonesia, Indonesia \\ Email: indrabudiman@ui.ac.id , inayati@ui.ac.id
}

Abstract. This research examines the two components of the Slippery Slope framework, power, and trust, in influencing formal tax compliance in the West Sumatera and Jambi region. The supervision factors: Notice of Tax Warning and Notice of Tax Collection are used as a proxy of power, and public education program is used as a proxy of trust in the authority. Secondary data collected through documentation study is presented in panel data and then analyzed using panel data regression analysis. As this study uses a mixed quantitative and qualitative method, we conducted in-depth interviews with key informants to get a more robust analysis. This study shows that together and partially, these three factors have a positive and significant effect on formal tax compliance. Notice of Tax Warning and Notice of Tax Collection effectively deliver law enforcement's message as a coercive power through supervision efforts. At the same time, tax education programs are practical to encourage awareness and trust in the authority that ultimately improves tax compliance. This study recommends some improvements in administrative issues and strategies to reach more taxpayers, perform more fair treatment, and enhance compliance.

Keywords: Tax Warning; Tax Education Program; Tax Compliance.

\section{Received:23-04-2021 Revised:24-05-2021 Accepted:29-05-2021}

\section{INTRODUCTION}

The tax ratio issue is rooting in the main problem faced by most tax authorities in the world: tax compliance. As a tax authority in Indonesia, the Directorate General of Taxes collects tax as state income by a self-assessment system that gives taxpayers the confidence to calculate the tax amount and make the payment independently. By implementing this system, supervision efforts and law enforcement are essential for ensuring tax obligation fulfillment reliability through voluntary and enforced compliance to manage the revenue effectively and equitably. However, compliance is still becoming a central issue for Indonesia. DGT still encounters tax collection constraints because of the taxpayers' disobedient behavior by avoiding and evading taxes. This notion is supported by the formal compliance data from DGT that are considerably low even after the 
implementation of the tax amnesty program with $60.7 \%$ (2016), $62.89 \%(2017), 68.55 \%(2018)$, and $72.52 \%$ (2019) (Directorate General of Taxes, 2020)

The same trend showed by West Sumatera and Jambi Regional Tax Office. Even though the number of registered taxpayers increased over time with 1.140.446 (2016), 1.1216.704 (2017), 1.316.711 (2018), and 1.428.331 (2019), support form submitting system (e-filing), and many efforts conducted to encourages taxpayers to comply; this regional office has never achieved the formal tax compliance target. In the same period, this office only reached $60,22 \%$ in 2016 , and this figure increased significantly to 82,26\% in 2017. In 2018 and 2019, this number dropped gradually to a low of $74,67 \%$ and $67,60 \%$, respectively. It is crucial to investigate the factors influencing compliance and measure the significance of each element for both corporate and individual taxpayers based on specific theories.

One theory used to analyze tax compliance is the Slippery Slope theory by Kirchler (2013). It argues that the knowledge of taxpayers and taxpayers' participation is highly connected with trust in the current compliance framework. Meanwhile, poor perception and misinterpretation are positively related to mistrust. Hence, better recognition of taxes will lead to better tax compliance, and poor insight will lead to lower tax obedience. Most people consider that tax law is too complex to be understood, requiring tax authority to increase taxpayers' literacy by training and education. Furthermore, Gangl et al. (2012) argue that trust in authority associated with the synergistic atmosphere produces willing cooperation.

Using this framework as a conceptual tool requires some factors to be investigated to see the correlation between power and trust in the compliance concept. Naicker \& Rajaram (2019) argued that tax compliance could be described as the arrangement, capitulation, and deposit of taxes within the definitive due date. Based on this definition, ensuring these complex activities are implemented is considered demanding and time-consuming in the tax administration system (LE et al., 2020). In terms of compliance, Devano \& Rahayu (2006) argue that taxpayer compliance is a sense of guilt and shame, taxpayer's point of view of equity of the burden they bear, and the effect of satisfaction on government service.

To see the concept from a tax administration context, authorities' power means conducting tax supervision, and trust can be encouraged through tax education programs. Tax supervision can be defined as a kind and steady form of deterrence and relationship between a tax authority and the firms or taxpayers. It allows controlling the taxpayers' awareness about auditing while avoiding unfriendly communication (Gangl et al., 2014). The supervision activities as one of the main processes in a tax authority include all efforts to detect non-compliance with tax obligations, such 
as non-registration, non-reporting or underreporting of income, or overestimating income deductible expenses. Soemarso (2007) states that supervision is a sequence of activities on finding, gathering, and processing data and/or information to check the compliance of tax obligations and other objectives to implement the provisions of law and regulations. For the formal obligation, giving warnings and sanctions are usually parts of supervision activities.

As one of the means of tax supervision, sanctions for non-compliant taxpayers can affect their awareness to be compliant. Tax sanctions are proven as one of the factors that influence taxpayer compliance by some researchers. According to Mardiasmo (2016), taxation sanctions guarantee that the provisions of legislation - taxation norms will be obeyed. In other words, a sanction is a deterrent so that taxpayers do not violate taxation norms. Mulder (2016) also states that by installing a sanctioning system, policymakers base their decision on the idea that a sanction changes the attractiveness of undesirable behavior, such as tax evasion, which deters people from engaging in it. Yuesti (2019), who researched tax compliance by examining the correlation of tax sanctions with tax compliance in individual taxpayers in Denpasar, concludes that tax sanctions positively affect it. In her study, she finds sanctions as one of the government's efforts to tie up taxpayers' responsibilities has increased taxpayer's compliance. Besides, Putra \& Hidayat (2018) argued that sanctions might indicate that a taxpayer does not comply with taxation or noncompliance with regulations that the tax law has made. Many sanctions are contained in the field of taxation formally and materially.

Organization For Economic Co-Operation And Development (OECD) (2004) argued that in choosing and applying treatment strategies to increase taxpayer compliance, ensuring that the taxpayers know their obligations and see them as easy to fulfill is the first move. This strategy is related to tax authority actions to inform the taxpayers through education programs, such as workshops, consultation, seminars, and media campaigns. According to Olowookere \& Fasina (2013), taxpayers' education can be explained to educate the people about the entire taxation process and why they should pay taxes. This approach helps them to meet their obligation to the states. The main benefits gain from taxpayer education programs is to strengthen voluntary compliance. As explained by (Akumbo et al., 2020), who investigate tax education and tax compliance in Ghana, tax education enhances taxpayers' knowledge by improving their technical skills to fulfill their tax obligation increasing their awareness of tax regulations. This finding has answered the main challenge in implementing tax law in Ghana: the lack of sufficient information flow of accountability methods, knowledge about tax policies, and awareness of available sanctions 
for non-compliance taxpayers. Furthermore, tax education in individual taxpayers mobilizes the tax revenue through several ways that boost their knowledge level.

From the formal tax compliance perspective that is becoming the focus of this study, efforts that can be used to analyze supervision are the actions taken to give warnings and penalties for non-compliant taxpayers. It means penalizing those who do not submit the annual tax return by issuing Notice of Tax Warning and Notice of Tax Collection. These notices are the first tax supervision effort that can be done immediately to give the message that tax authority controls and supervises the taxpayers.

The importance of investigating formal compliance is since the starting point of taxpayers to be audited by the tax authority is the condition in which they are "in the system." It means that they have already submitted their tax return. It is aligned with Alms \& Torgler (2011), who states that the typical models in tax compliance studies are too simplified by ignoring the obedience to fill or submit tax returns (formal compliance). We need to realize that before we move on the material compliance in counting, paying, and reporting tax debt, there is formal compliance in which tax authorities find whether taxpayers are submitting their tax returns or not. If they are not filing their return, they will be obviously out of the system and cannot be audited. If we do not pay more attention to this condition, a traditional approach to enhancing tax compliance through enforcement efforts will not be effective.

The originality of this research comes from the limitation of some previous studies. Many previous research studies primarily examine individual or corporate taxpayers and examine taxpayers' intention using primary data from the questionnaire to analyze material compliance. Unlike most literature that measure tax supervision's impact by using primary data collected through questionnaire survey, this research uses secondary data using taxpayers' data collected by the Directorate General of Taxes mixed with primary data from an in-depth interview with some informant. There is still limited research that discusses both these types of taxpayers. Therefore, this study will investigate corporate and individual taxpayers using secondary data of taxpayers' actual actions from regional-scale research sites, West Sumatera, and Jambi Regional Tax Office. Thus, this study will scrutinize some research questions on tax compliance: 1) How are the effects and significance of Notice of Tax Warning on tax compliance? 2) How are the effect and the significance of Notice of Tax Collection on tax compliance? 3) How are the effect and the significance of the Tax Education Program on tax compliance?

The scope of this research focuses on measuring the influence of tax supervision and tax education programs on formal tax compliance. This study aims to measure the effect and 
significance of Notice of Tax Warning, Notice of Tax Collection, and tax education programs on formal tax compliance. The hypothesis proposed as the answers to the research problems are: 1) There is a positive and significant effect of Notice of Warning on formal tax compliance. 2) There is a positive and significant effect of Notice of Tax Collection on formal tax compliance. 3) There is a positive and significant effect of tax education programs on formal tax compliance.

\section{METHODS}

This study uses the mixed method of the quantitative method with explanatory study and qualitative method. We apply this method to get a more comprehensive result by validating and explaining the statistical analysis with the qualitative approach to strengthen the validity and reduce the bias of the results. We use secondary data of tax compliance in West Sumatera and Jambi Region in four years-period (2016-2019) through documentation study, and primary data through in-depth interviews with key informants to enrich our comprehension and get the specific reason and description of the research site practices.

The compliance data of corporate and individual taxpayers include the number of registered taxpayers, the number of taxpayers who are obliged to submit a tax return, and the submitted annual tax return. Supervision effort data consists of the number of Notice of Tax Warning and Notice of Tax Collection. Lastly, the data for the effectiveness of education programs includes the number of targets and realization of public education programs that have been conducted from 2016 to 2019 in ten Tax Offices in West Sumatera and Jambi Regional Tax Office. All secondary data is aggregated data at the Tax Office level. This paper uses the common effect model (CEM) of the panel data regression method to measure the relationship between variables using the Stata statistics application. It also applies heteroscedasticity and multi-collinearity test to check the robustness of the results. After all regression models fulfill the classical assumption, we conduct the t-test and F-tests to verify the regression coefficient significance to test the hypothesis.

Apart from using the documentation method, this study also uses the interview method to complement the correctness and stability of the data obtained through the documentation method. We interviewed some essential roles and representative people from the Regional Office: Head of Section of Tax Data and Potential, Head of Section of Tax Counseling, Head of Division of Tax Objection, Appeal, and Deduction, and Tax Counselor. Besides, we also asked four taxpayers, a tax consultant, and three tax experts from the University of Andalas and Padang State University. 


\section{RESULTS AND DISCUSSION}

The classical assumption tests carried out include the multi-collinearity test and heteroscedasticity test. The Multi-collinearity test is intended to determine whether it presents perfect inter-correlation between several independent variables used in the model. The result of the multi-collinearity test using Stata software is shown in Table 1.

Based on the output, we can see that the tolerance value of X1 0.281550 is bigger than 0.1 . Also, the tolerance value of $X 20.481351$ and $X 30.284626$ is also bigger than 0.1 . In terms of the value of VIF, variable $\mathrm{X} 1, \mathrm{X} 2$, and $\mathrm{X} 3$ also show the value that are less than 10 with $3.55,2.08$ and 3.51 respectively. The VIF value of all independent variables are less than ten, and the tolerance values are more significant than 0.1 . These results show that there is no multi-collinearity indication among the independent variables in this regression model. It means there is no correlation between our independent variables Notice of Tax Warning, Notice of Tax Collection, and Tax Education Programs. So, we can rely on this analysis to test our hypothesis, and it will give a more stable and precise measurement of formal compliance.

The result of the heteroscedasticity test using Stata software is presented in Figure 1 below. Heteroscedasticity is a condition where there is an inequality of variants of the residuals from one observation to another in the regression model. Based on the Glejser test, heteroscedasticity exists if the value of Prob > chi2 is less than the value of a (0.05). From this output, the value of Prob > chi2 is 0.1814 is more significant than 0.05 , which means there is no heteroscedasticity indication in the regression. The fact that our measurements free of this indication can give the validity of statistical significance.

We also conducted the $\mathrm{F}$ test to test whether all the independent variables included in the model have a joint influence on the dependent variable. The independent variables together are said to significantly affect the dependent variable if the value (Prob > F $\}$ is less than the a value of 0.05 or the value of F-test > F-table. From the hypothesis test using F-Test as shown in Figure 2, we get the result of F-statistics 0,6967, and the value of F-Table is 4,74. As shown in Table 2, the result of Prob $>F$ is 0.0000 , and this number is smaller than the a value of 0.05 . Since the value of F-test $>$ F-table, and the Prob $>\mathrm{F}$ is less than 0.05 , it can be concluded that together or simultaneously, the Notice of Tax Warning, Notice of Tax Collection, and Tax Education Program variables significantly influence the Formal Tax Compliance. 
Table 1.

Multi-collinearity Test Result (VIF)

\begin{tabular}{lll}
\hline Variable & VIF & 1/VIF \\
\hline Notice of Tax Warning (X1) & 3.55 & 0.281550 \\
Notice of Tax Collection (X2) & 2.08 & 0.481351 \\
Tax Education Program (X3) & 3.51 & 0.284626 \\
\hline Mean VIF & 3.05 & \\
\hline
\end{tabular}

Source: Output of Data Processing with Stata Software (2021)

Figure 1.

Heteroscedasticity Test Result

Breusch-Pagan / Cook-Weisberg test for heteroskedasticity

Ho: Constant variance

Variables: fitted values of Compliance

$\operatorname{chi2}(1)=1.79$

Prob $>$ chi2 $=0.1814$

Source: Output of Data Processing with Stata Software (2021)

Figure 2.

F-test Result

$$
\begin{gathered}
\frac{R^{2} /(k-1)}{\left(1-R^{2}\right)(N-k)}=\underline{0,9070 /(3-1)}=0,6967 \\
(1-, 9070)(10-3)
\end{gathered}
$$

Source: Processed by Researcher using F-test Formula (2021)

Table 2.

Regression Estimation Result of Common Effect Model

\begin{tabular}{llll}
\hline Variable & B & $\mathbf{t}$ & Sig. \\
\hline & .1458933 & 3.99 & 0.000 \\
Notice of Tax Warning & .5323424 & 5.92 & 0.000 \\
Notice of Tax Colection & .0651759 & 1.73 & 0.042 \\
Tax Education Program & .1176468 & 3.41 & 0.002
\end{tabular}

Source: Output of Data Processing with Stata Software (2021)

Table 2 shows the regression estimation results to see the value of $\{P>|t|\}$. The t-test is conducted to determine how much one independent variable's influence explains the dependent 
variable. This research will prove the effects of each of the independent variables on the dependent variable. The independent variable is said to have a significant effect on the dependent variable if the value $\{P>|t|\}<$ the value of $a$ that is 0.05 or t-test $>t$ table. From the estimated regression result from the Stata, we get the information to test our hypothesis as follows:

\section{Hypothesis 1: There is a positive and significant effect of Notice of Warning on formal tax compliance.}

The value of $\{P>|t|\}$ Notice of Tax Warning is 0,000 . This value is lesser than the value of $a$ 0.05 . We can also see this relationship by examining the value of t-statistics and t-table. The value of t-table at $5 \%$ level of significance and $d f 7(n-k=10-3)$ is 2.3646 . From the regression result, we get the value of t-statistics 5.92 , and this value is greater than the value of the t-table. It means Notice of Tax Warning has a significant influence on Formal Tax Compliance.

The Notice of Tax Warning variable provides a positive coefficient estimation result following the initial hypothesis. The results of the t-test show that the Notice of Tax Warning variable has a significant effect on the Formal Tax Compliance at alpha 5 percent. Furthermore, regarding the magnitude of the influence of Notice of Tax Warning on formal tax compliance, it can be seen from the regression coefficient value of the variable, which is .5323424 . Therefore, we can conclude that the Notice of Tax Warning positively and significantly affects the formal tax compliance in West Sumatera and Jambi Regional Tax Office, meaning Hypothesis 1 is accepted.

\section{Hypothesis 2: There is a positive and significant effect of Notice of Tax Collection on formal tax compliance.}

The value of $\{P>|t|\}$ Notice of Tax Collection is 0,042 . This value is lesser than the value of $a 0.05$. From the regression result, we get the value of t-statistics 1.73 , which is lesser than the value of the t-table. It means Notice of Tax Collection has a significant influence on Formal Tax Compliance. The Notice of Tax Collection variable provides a positive coefficient estimation result following the initial hypothesis. The results of the t-test show that this variable has a significant effect on formal tax compliance at the 5 percent significance level. Furthermore, regarding the magnitude of the influence of Notice of Tax Collection on the formal tax compliance, it can be seen from the regression coefficient value of the variable, that is .0651759 . Hence, it can be concluded that the Notice of Tax Collection positively and significantly affects the formal tax compliance in West Sumatera and Jambi Regional Tax Office, and we accept Hypothesis 2. 


\section{Hypothesis 3: There is a positive and significant effect of tax education programs on formal tax compliance.}

The value of $\{P>|t|\}$ Tax Education Program is 0,002 . This value is lesser than the value of a 0.05 . From the regression result, we get the value of t-statistics 3.41 , which is greater than the value of the t-table. It means Tax Education Programs have a significant influence on Formal Tax Compliance. The Tax Education Program variable shows a positive coefficient estimation result following the initial hypothesis. Besides, the results of the t-test show that the Tax Education Program variable has a significant effect on the Formal Tax Compliance at alpha 5 percent. Furthermore, regarding the magnitude of the Tax Education Program's influence on formal tax compliance, it can be seen from the regression coefficient value of the variable .1176468. So, Hypothesis 3 is accepted, meaning that the tax education program positively and significantly affects the formal tax compliance in West Sumatera and Jambi Regional Tax Office.

\section{Effect of Notice of Tax Warning on Formal Tax Compliance}

As issuing a Notice of Tax Warning aims to remind the taxpayers that their obligation is not yet fulfilled, it is practical to alert them that DGT always keeps an eye on them. Based on West Sumatera and Jambi's practices, Notice of Tax Warning has the highest significant level among the variables in this research could be caused by the treatment and the supervision in issuing this notice.

The first factor identified in determining this positive and significant influence is the implementation of this notice is firmly executed to detect and warn taxpayers. Notice of Tax Warning is always a part of the strategy to enhance compliance in DGT. This notice is often regulated in the Circular Letter of Director-General of Taxes, which tells about the time and prioritized target. By sending this notice immediately after the due date, it gives a strong impression that taxpayers will be aware that DGT is seriously enforcing the law and regulations and making them more aware of their responsibility as taxpayers. This notice also suits the local wisdom more appreciating the humanist and persuasive way than the notice that strictly told the sanction and legal consequences. As our respondent from DGT said, "the taxpayers feel that DGT still provides room for them to fulfill the obligation without worrying about the sanctions."

Charoline Cheisviyanny, a tax expert and manager of the Tax Policy and Accounting Research Centre of Padang State University, explained that in theory, the Notice of Tax Warning for submitting tax returns makes taxpayers more aware that there are obligations that have not been fulfilled. This notice will be more effective when issued soon, so taxpayers will not forget and their business conditions have not changed much. Therefore, the intentions contained in this letter 
will be more conveyed. Moreover, another reason why Notice of Tax Warning shows the positive and significant influence on triggering taxpayers to submit their tax return is the ability to detect taxpayer who does not file the tax return, as stated by Dr. Fauzan Misra, SE., M.Sc., Ak., CA, tax expert in the University of Andalas. He said that the Notice of Tax Warning could positively and significantly influence compliance because this letter can detect taxpayers who do not report it better than other letters. The taxpayer considers the warning to drive them to think that the DGT can easily see if they do not submit their tax return. The public has accepted this without going through the sanctions processes in the Notice of Tax Collection.

The second reason is this notice has a characteristic as a reminder for the taxpayer. Some taxpayers get this letter as a reminder that it is part of the soft approach performed by the tax office. A corporate taxpayer respondent states his feeling after receiving this letter in 2018 . He says that "this notice makes us realize that our obligations have not been fulfilled yet and there will be consequences. This reminder encourages us to be more aware of our obligation next time." Moreover, Notice of Tax Warning is a manifestation of the self-assessment system in Indonesia. Rahmat Kurniawan, a tax expert from the University of Andalas said, "in this system, at first, taxpayers are asked to carry out their obligations voluntarily, starting from calculating, depositing, and reporting Tax Returns. The issuance of this warning is carried out as a form of DGT's role to encourage taxpayers to implement this system by giving early warning, which is mandated by the KUP Law, not directly to law enforcement actions." This finding is in line with the research of Carpio (2014), who examine the impact of tax payment reminders in Peru. He finds that the tax reminder can explain half of the significant increase of compliance of his research subject, taxpayers of property tax. Furthermore, it also confirms the study of Nasution et al. (2020), who examine the implementation of tax reminder messages to enhance taxpayer's compliance in submitting tax returns in North Sumatera. This study reveals that tax compliance levels are better after implementing the reminder because it reaches more taxpayers and conveys the message effectively.

The third reason determining the significance of this notice is the fairness perceived by the taxpayers. When all non-filing taxpayers get the same message that reminds them that there is an unfulfilled obligation, they will feel more aware. This feeling will be stronger when they found that their disobedient colleagues or friends also got the same treatment. This fair treatment evokes the justice felt by the taxpayers. Taxpayers will feel fairness when they have a perception that the authority performs fair procedures and services. This reasoning is in line with Murphy, Bradford, \& Jackson (2015), who investigate procedural fairness in determining the overall fairness judgment. 
They found that the treatment experienced by individuals during interaction with a tax authority is vital to indicate taxpayers' status within a group. If a tax agency treats every taxpayer fairly and respectfully, the status of this taxpayer as a valued member of the group is reinforced. In this study, the authority has tried to treat all non-compliance taxpayers fairly by issuing Notice of Tax Warning to almost all taxpayers to support the importance of every taxpayer. Moreover, Ramirez Zamudio \& López-Pérez's (2018) study supports these findings by saying that taxpayers are more likely to pay taxes to the government if they believe that other citizens give as well.

Based on the data of the non-filing taxpayers who are issued this notice in the last four years, tax offices in this region took higher effort and tried to reach all taxpayers in sending this notice. In our data, only four observations are issuing this notice to less than 50 percent of non-filing taxpayers, and it only occurred in two tax offices. The other 36 observations give this notice massively to more than 50 percent of the non-submitting group, with 22 observations achieving more than 70 percent to 95 percent. This effort shows that the supervision conducted by issuing Notice of Tax Warning broadly will significantly affect taxpayers when they all can be reached out. This practice indicates that DGT as a tax authority can use the power it has to enforce taxpayers to comply with the law and regulation. It confirms the concept of the power of authority in the theory of Slippery Slope.

\section{Effect of Notice of Tax Collection on Formal Tax Compliance}

This variable also shows a positive influence on formal tax compliance. However, the value of beta is lower, with 0.0651759 . As an initial stage of tax supervision, Notice of Tax Collection positively affects formal tax compliance. It is caused by the deterrence message that is delivered through this letter. In Notice of Tax Collection, the taxpayers have already been informed of the fine they should pay, the due date, and the further consequences if they ignore the letter. This result is supported by Castro \& Scartascini's (2015) research, which conducted a field experiment about deterrence messages to treat non-comply taxpayers. They write down the simplified example of the cost if they perform as noncompliance and the potential debt would be if not paid in a year. They also state that this message's objectives are: 1) to enhance the taxpayers' perception of the possibility of being fined and other administrative sanctions by becoming non-compliant taxpayers and 2) to decrease the additional cost arise from a compound interest rate from unpaid tax.

The deterrence effect brought by sanction in influencing tax compliance is also shown by Robbins \& Kiser (2019), who find the strong effects of detection and severity of punishment on intentions to comply by examining the new sociology of morality and moral psychology. By conducting a factorial survey experiment and a survey questionnaire to income taxpayers, he 
reveals that taxpayers who encounter a penalty or higher probability of detection tend to report their payments rather than taxpayers who experience weaker sanctions or lower probability of detection.

Our respondents agree with the statement that sanctions delivered through Notice of Tax Collection can strengthen taxpayers' perception of becoming a compliant taxpayer and avoiding or minimizing the further fine probability. Besides, a Tax Lecturer at the University of Andalas, Dr. Fauzan Misra, SE., M.Sc., Ak., CA, also said that "sanctions are still considered a promising approach in supervising taxpayers to enhance compliance. Imposing sanctions refer to psychological factors to encourage taxpayers to comply. In my view and several studies that I have conducted, for the tax environment in Indonesia, we cannot leave the sanctions approach yet and switch to sociology-based or community-based approaches."

From the Head of Division of Objection, Appeal and Deduction of West Sumatera and Jambi Regional Tax Office, Notice of Tax Collection can lead the taxpayers to perform positive attitudes towards compliance because it can trigger the awareness that DGT seriously enforces the regulations. Besides, He adds that Notice of Tax Collection has further law consequences and makes taxpayers feel intimidated when they are supervised.

The second reason why Notice of Tax Collection is a form of formal sanction is significant to influence formal tax compliance: taxpayers believe that being sanctioned means breaking moral norms. This finding is supported by Mulder (2016), who said that sanctions are characterized not only by the strength to deter people from undesired behavior but also by the ability to convey moral norms. Some taxpayers do not want to be seen as tax offenders in the community. It is supported by the common reasons of taxpayers who apply for tax sanction abolition to the Division of Objection, Appeal, and Deduction in West Sumatera and Jambi Regional Tax Office. The Head of this division said that based on the summary of application data, most taxpayer's requests to abolish their sanction enclose the argument that they want to keep their record clear as a good taxpayer and do not want to have an offender history.

These findings align with the classical sociologist (Durkheim 1961, 1965; Goffman 1959; Weber 1930 in Mulder, 2016) who said that morality and moral attitudes are essential and more fundamental than deterrence. Many tax literature has shown that most people are still willing to pay tax even though the possibility of getting caught when you do not pay tax is low. It described that taxpayers fulfill their obligation based on internalized norms, like ethics (Alms \& Torgler, 2011). The understanding of taxpayers leads these attitudes that paying tax is a responsibility to the community and the country (Williamson, 2017). It is confirmed by our respondents' respond who state that "even though there are many manipulation and corruption cases discouraging people from paying 
tax. But, for me, this is my obligation to the state as a taxpayer." Moreover, Robbins \& Kiser (2019) suggest that tax obedience is not solely coercive or quasi-voluntary; it is principally voluntary where the roots of uncoerced tax compliance trunk from the moral attitudes and judgments attach to taxes and taxation. Furthermore, Carpio (2014) also finds that norms treatment raises taxpayer's belief about tax compliance and positively impacted the level of compliance, and affects evasion decisions.

This finding is in line with the statement from our respondent, who is a representative of corporate taxpayers. She said that "our company performance is always controlled by stakeholders, includes our peers and customers. They believe that we are a good company that obeys all the regulations. Tax is a sensitive issue for us, so we have to ensure that we do not have this kind of problem, such as being fined or not fulfilling our obligation, that will affect our image in society."

This condition shows that some taxpayers intentionally want to keep their image good in society by not breaking up the rules. It will directly or indirectly influence their business sustainability, especially for certain types of taxpayers like banks or government partners in goods procurements. When they are being sanctioned, their partner or customers will see them as offenders, and to some extent, this is not accepted by reference groups.

This statement suits the research results by Kirchler (2007), who states that social norms impact is widely considered as one of the paramount factors in tax compliance. Also, Luttmer \& Singhal (2014) supports this thought by saying, "individuals may be influenced by peer behavior and the possibility of social recognition or sanctions from peers. It can further affect the strength of these intrinsic motivations." For example, a taxpayer's perception of tax compliance can be influenced by group communication. As suggested by Robbins \& Kiser (2019), "moral attitudes are developed and shaped by interpersonal communication, as well as by values and standards discussed, approved and communicated in the community." This literature idea has confirmed our result in this study that the Notice of Tax Collection can encourage taxpayers to obey the rules and regulations as a form of sanction imposition. They perceive that paying tax is a good value, and they do not want to break the moral norms believed in their community or broader society. This result supports the element of power in the concept o slippery slope to influence taxpayer's compliance.

\section{Effect of Tax Education Program on Formal Tax Compliance}

By analyzing the result of data regression in this research, we know that Tax Education Program performed by DGT shows a positive and significant effect. From the value of beta (0.1176468), this variable is the second most dominant factor in the equation in influencing formal 
tax compliance in West Sumatera and Jambi Regional Tax Office. We get three primary reasons for this influence. The first reason is the program sets right on target, covers all the knowledge needed to comply, and suits taxpayers' status and business type. Each program is designed to be suitable for the targeted taxpayers, both the materials and the activity. Therefore, we can say that the education programs conducted have embraced all potential segments that will contribute to compliance in taxation. One event that can be an example is a program related to non-compliant groups in West Sumatera and Jambi Regional Office is the seminar and technical assistance conducted to taxpayers who did not submit a tax return in the previous fiscal years.

The reason for this significance is explained by the Tax Counsellor of West Sumatera and Jambi Regional Tax Office. Based on the interview result, he said that "tax education programs play essential roles in encouraging taxpayers to be aware of their obligations. In the registration stage, a new taxpayer has been explained the responsibility, how, and when to do it. They are also informed and updated with the new regulations by inviting them to many disseminations and public campaigns. These many tax education programs show that DGT is always there to help taxpayers comply." This practice ensures that taxpayers have no reason to perform non-compliant attitudes with the excuse of having no knowledge and ability to meet their obligations to the state. This result corresponds with the research by Mukhlis, Utomo, \& Soesetyo (2014), who found that tax education programs can effectively influence the compliance attitudes of SME entrepreneurs in East Java. It can be explained by the material of tax dissemination that suits the economic activity of the taxpayers. Also, they uncover that some socialization activities will be effective when it is conducted by tax officers that include direct communication with taxpayers and pay attention to social-cultural aspects. It is essential to escalating the public interest in bringing about economic activities.

Looking more closely at the condition in the research site, West Sumatera and Jambi Region, education programs significantly encourage taxpayers' compliance. It is caused by the level of education of most taxpayers, especially in tax matters, which is considerably low. Rahmat Kurniawan, SE, MA, Ak, our lecturer respondent from the University of Andalas, said that "in my opinion, the level of education, knowledge of taxpayers, especially at the middle class, in West Sumatera in particular, is still low. So that education and socialization play an important role in enhancing their knowledge." He suggests that to make this education more effective, DGT can collaborate with other parties, such as a university or consultant association. He adds that this will make taxpayers open and may psychologically receive the material without the feeling of defensiveness, compared to the education directly carried out by the DGT. 
The second reason that can be identified to know how a socialization program affects the awareness and the behavior of the taxpayers is a better awareness and behavioral change. We can see it from the orientation theory by Almond \& Verba (1963), who stated that orientation could be divided into three forms: cognitive orientation, affective orientation, and evaluation orientation. Cognitive means knowledge of and belief about the object of socialization, its roles, inputs, and outputs. Taxpayers will get new or more detailed knowledge about tax matters after attending a tax education program. Affective orientation means feeling about the material they get, its roles, and performance. Knowledge from socialization will lead them to feel the information in real life. For instance, is it true that public facilities are funded by tax? Finally, their knowledge and feeling will encourage them to judge their actions towards tax. For example, is my decision to register as a taxpayer to submit my tax return is the right action?

After getting the correct information and understanding the tax regulations, taxpayers can feel, judge, and finally perform compliant behavior. Our respondent shows this way of thinking when being asked about behavioral change after joining a seminar. She said that "I get better knowledge from socialization. Besides the specific and technical material about taxation, the tax office often gives material related to tax revenue benefits such as the use for state development."

Corresponds to the trust in the Slippery Slope Framework, tax education programs can affect taxpayer's trust. A study by Fahr \& Djawadi (2013) proved that taxpayers are more likely to trust the tax agency when they have adequate tax knowledge, leading to tax compliance. The importance of tax education programs that can contribute to pushing the compliance rate is also shown by the research of Kirchler (2013). They state that training and other education programs can increase taxpayers' literacy by simplifying the tax law that is initially considered too complex. Palil \& Rusyidi (2013) also found that taxpayers with low tax education and knowledge perform lower tax compliance. In other words, by having proper tax knowledge, they will determine whether to trust the tax authority. This emersion of trust will ultimately influence the decision of taxpayers to comply with their tax obligation.

This study found that tax education programs by tax offices in West Sumatera and Jambi region have accommodated needs from several levels and types of taxpayers. We know that DGT has implemented various programs leads by the target to fulfill some taxpayers' needs. By categorizing the audience and the material that suits taxpayers' business, it helps to cluster the regulations and technical skills needed for certain types of taxpayers. So the taxpayers do not see these regulations and administration are too complex to fulfill. These well-organized plans help the tax offices send the message about tax knowledge to the taxpayers effectively. It will improve their 
awareness of their obligation, trust in authority and ultimately lead to more compliant behavior that confirms the concept of the Slippery Slope Framework.

Based on the results, the broad significance of the study would be the improvement in the understanding of supervision and education efforts to affect the formal tax compliance. Practically, this study can be used to evaluate current tax policy effectiveness related to tax compliance and to redesign tax policies to improve tax compliance, yielding the best outcomes from supervision and educational aspects aligned with the DGT Regulation Framework matrix for 2020-2024.

\section{CONCLUSIONS}

Based on the findings and discussion, we conclude that: 1) Notice of Tax Warning positively and significantly influences the formal tax compliance at West Sumatera and Jambi Regional Office with a determinant value of $53,23 \%$. This figure denotes that the higher the percentage of tax warning issued, the higher the compliance level achieved. 2) Notice of Tax Collection positively and significantly influences the formal compliance level at West Sumatera and Jambi Regional Office. It is shown by the determinant value of $6,52 \%$, which indicates that the higher the number of Notice of Tax Collection issued in the supervision effort, the higher the achievement of formal compliance at West Sumatera and Jambi Regional Office. 3) Tax Education Program positively and significantly affects formal compliance of submitting a tax return in West Sumatera and Jambi Regional Tax Office by having a determinant value of $11,76 \%$. This number represents that the higher the effectiveness of Tax Education Programs, the higher the formal compliance level achieved. These variables significantly affect formal compliance because they can reach and touch all types and levels of taxpayers. It also suits the local wisdom and characteristics that more appreciates the soft approaches.

It is suggested to the Directorate General of Taxes to consider a strategy to set up the supervision office in a remote location and collaborate with the third party like university and consultants in conducting education programs. It will help ensure that it can effectively implement the law and tax education and make sure that no groups of taxpayers are neglected anymore. Besides, DGT needs to redesign the sanction regulations by combining them with a soft approach, especially for taxpayers who already follow up the warning letter as the first effort to touch the noncompliant taxpayers. For future research, it is suggested to use more detailed data from each variable to mitigate and reduce the potential bias from the measurements of aggregate data. It could be in more detail information about taxpayers such as individuals or corporate and 
businessmen or employees because each type may show different attitudes in responding to every supervision and effort conducted by the tax authority.

\section{REFERENCES}

Akumbo, S., Mbilla, S., Abiire, A., Atindaana, P., Ayimpoya, R., \& Ghana, I. (2020). Tax Education And Tax Compliance.

Almond, Gabriel., Verba, S. (1963). The Civic Culture : Political Attitudes and Democracy in Five Nations. Princeton University Press.

Alms, J., \& Torgler, B. (2011). Do ethics matter? Tax Compliance and Morality. Journal of Business Ethics.

Carpio, L. (2014). Are the Neighbors Cheating? Evidence from a Social Norm Experiment on Property Taxes in Peru. Job Market Paper.

Castro, L., \& Scartascini, C. (2015). Tax compliance and enforcement in the pampas evidence from a field experiment. Journal of Economic Behavior \& Organization, 116, 65-82. https://doi.org/https://doi.org/10.1016/j.jebo.2015.04.002

Devano, S., \& Rahayu, S. . (2006). Perpajakan: Konsep, Teori dan Isu. PT. Kencana.

Fahr, R., \& Djawadi, B. M. (2013). The impact of tax knowledge and budget spending influence on tax compliance (IZA Discussion Paper 7255). https://papers.ssrn.com/sol3/papers.cfm?abstract_id=2234277

Gangl, K., Hofmann, E., Pollai, M., \& Kirchler, E. (2012). The dynamics of power and trust in the 'slippery slope framework' and its impact on the tax climate. SSRN Electronic Journal.

Gangl, K., Torgler, B., \& Hofmann, E. (2014). Effects of supervision on tax compliance: Evidence from a field experiment in Austria. Economics Letters, 123, 378-382.

Kirchler, E. (2007). The economic psycology of tax behavior. Cambridge University Press.

Kirchler, E. (2013). Trust and Power as Determinants of Tax Compliance: Testing the Assumptions of the Slippery Slope Framework in Austria, Hungary, Romania, and Russia. Journal of Economic Psychology, 34, 169-180.

LE, H., TUYET, V., HANH, C., \& Do, Q. H. (2020). Factors Affecting Tax Compliance among Smalland Medium-sized Enterprises: Evidence from Vietnam. The Journal of Asian Finance, Economics and Business, 7, 209-217. https://doi.org/10.13106/jafeb.2020.vol7.no7.209

Luttmer, E., \& Singhal, M. (2014). Tax Morale. Journal of Economic Perspective, 28(4), 149-168. Mardiasmo. (2016). Perpajakan Edisi Revisi. Andi.

Mukhlis, I., Utomo, S. H., \& Soesetyo, Y. (2014). Increasing tax compliance through strengthening 
capacity of education sector for export oriented SMES handicraft fields in East Java Indonesia. European Scientific Journal, 10(7).

Mulder, L. B. (2016). When sanctions convey moral norms. European Journal of Law and Economics.

Murphy, K., Bradford, B., \& Jackson, J. (2015). Motivating Compliance Behavior Among Offenders:

Procedural Justice or Deterrence? Criminal Justice and Behavior. https://doi.org/10.1177/0093854815611166

Naicker, Y., \& Rajaram, R. (2019). Factors that Influence Tax Compliance of SMEs in South Africa. Acta Universitatis Danubius: Administratio, Vol 10, 94-111.

Nasution, M., Santi, F., Husaini, H., Fadli, \& Pirzada, K. (2020). Determinants of tax compliance: A study on individual taxpayers in Indonesia. Entrepreneurship and Sustainability Issues, 8, 1401-1418. https://doi.org/10.9770/jesi.2020.8.2(82)

Olowookere, J. K., \& Fasina, H. T. (2013). Taxpayers ' Education : A Key Strategy in Achieving Voluntary Compliance in Lagos State, Nigeria. European Journal of Business and Management, 5(10), 146-155.

Organisation For Economic Co-Operation And Development (OECD). (2004). Compliance Risk Management: Managing and Improving Tax Compliance. Centre for Tax Policy and $\begin{array}{llll}\text { Administration } & \text { (CTPA), } & \text { October, } & \text { Hal: }\end{array}$ https://www.oecd.org/tax/administration/33818656.pdf

Palil, M. R., \& Rusyidi, M. A. (2013). The Perception of Tax Payers on Tax Knowledge and Tax Education with Level of Tax Compliance: A Study the Influences of Religiosity. ASEAN Journal of Economics, Management and Accounting, 1(1), 118-129.

Putra, A. M., \& Hidayat, N. (2018). The Influence Of Taxpayer Compliance And Tax Sanction On Amnesty Tax Participation. South East Asia Journal of Contemporary Business, Economics and Law, 16(5).

Ramirez Zamudio, A., \& López-Pérez, R. (2018). Social Norms and Tax Compliance: Experiments and Theory.

Robbins, B. G., \& Kiser, E. (2019). State Coercion, moral attitudes, and tax compliance: Evidence from a national factorial survey experiment of income tax evasion.

Soemarso, S. . (2007). Perpajakan Pendekatan Komprehensif. Salemba Empat.

Taxes, D. G. of. (2020). Rencana strategis direktorat jenderal pajak tahun 2020-2024.

Williamson, V. S. (2017). Read My Lips: Why Americans Are Proud to Pay Taxes. Princeton University Press. 
Yuesti, A. (2019). Correlation of Tax Behavior with Tax Compliance. International Journal of Innovation, Creativity and Change, 9(5). 